\title{
Factors Influencing Complication Rates at Colonic Polypectomy: A Prospective Study from a Tertiary-Referral Center
}

\author{
TH. VOIOSU ${ }^{1}$, B. BUSUIOC ${ }^{1}$, A. VOIOSU ${ }^{1}$, ANDREEA BENGUS ${ }^{1}$, M. RIMBAS ${ }^{1}$, \\ ROXANA DINU ${ }^{1}$, B. MATEESCU ${ }^{1}$, L. NEGREANU $^{2}$ \\ ${ }^{1}$ Gastroenterology Department, "Colentina" Clinical Hospital, Bucharest \\ ${ }^{2}$ Gastroenterology and Internal Medicine Department, SUUB, Bucharest
}

\begin{abstract}
Background and aims. Colon polypectomy decreases the incidence of colorectal cancer and related mortality. Several factors such as the size, location and type of polyp as well as endoscopist experience have been shown to correlate with the risk of ensuing procedure-related complications. This study aims to evaluate the impact of polyp and endoscopist-related factors on the rate of postpolypectomy complication in a real-life setting.

Methods. During the study period all polypectomies performed in our unit were reported on a standard form that included data on polyp type (flat, sessile, pedunculated), size, location in the colon, resection method, endoscopist volume and procedure-related complications arising up to 30 days. The main outcome was the complication rate of polypectomies. The factors that associated with a higher risk of complications were assessed on univariate and multivariate analysis.

Results. 244 polyp resections from 95 patients were included in the analysis. 199 polyps were resected by low-volume endoscopists $(44.7 \%)$ and 135 polypectomies were performed by highvolume endoscopists $(55.3 \%)$. On multivariate analysis only polyp size correlated with the risk of procedure-related complications.

Conclusion. Polyp size is the most important risk factor for procedure-related complications. Both high and low-volume endoscopists have a low overall rate of serious complications.
\end{abstract}

Key words:

\section{INTRODUCTION}

Endoscopic resection of colon polyps has been shown to decrease the incidence of colorectal cancer [1]. Although most complications related to polypectomy are self-limited, serious complications and, rarely, death can occur as a result of this procedure [2]. Several characteristics such as increased size, right colon location and flat lesions have been linked with an increased risk of complications [3, 4]. A low volume of procedures per endoscopist has also been cited as an independent risk factor for complications [5]. This data suggests that not all polyps and endoscopists were created equal, with certain lesions requiring an advanced set of endoscopic skills. Recent studies have tried to evaluate polypectomy competency using predefined parameters [6], while some authors have even suggested assessing the potential difficulty of the procedures using a scoring system in order to stratify the risk of the procedure and the skill level required to attempt a particular polypectomy [7]. We aimed to explore polyp and endoscopist-related factors that might influence complication rates after colon polypectomy in a real-life setting.

\section{MATERIALS AND METHODS}

We performed a prospective observational study in the Gastroenterology Department of "Colentina" Clinical Hospital between January and December 2014. Endoscopists were asked to report on all colon polypectomies using a standard form. Data was collected regarding polyp type (flat, sessile, pedunculated), size, location in the colon, resection method (hot snare, cold snare, biopsy forceps, piece-meal mucosectomy), endoscopist volume ( $<1000$ colonoscopies / > 1000 colonoscopies) and procedure-related complications arising up to 30 days. The procedures were performed using EXERA II 160 series Olympus colonoscops and ERBE 200 electrosurgical units.

The main outcome assessed was the complication rate of polypectomies. For this study we considered as relevant complications perforation diagnosed endoscopically and/or by radiological assessment, and polypectomy-related hemorrhage defined as bleeding severe enough to require any form of therapeutic intervention (including but not limited to blood transfusions, endoscopic therapy or surgery). 
Statistical analysis was performed using SPSS software package for Windows Version 16.0 (SPSS Inc., Chicago, IL). Results are expressed as frequencies for categorical variables (further analyzed by Fisher's exact test), mean and standard deviation for normal continuous variables (analyzed by Student's $t$ test), and median and extremes for nonnormal continuous variables (analyzed by the MannWhitney $U$ and Kruskall Wallis tests). Logistic regression was performed to evaluate polyp and endoscopist related factors that might influence complication rate for colon polypectomy. Hypothesis testing was 2-tailed, with $\mathrm{p}<0.05$ considered statistically significant.

\section{RESULTS}

During the study period 95 patients had complete study forms that reported the outcomes of 244 colon polypectomies performed by 15 endscopists. One hundred nine polyps were resected by low-volume endoscopists (44.7\%) and 135 polypectomies were performed by high-volume endoscopists (55.3\%) (range $1-64$ polyps per endoscopist).
Most polyps were $<10 \mathrm{~mm}$ in diameter $(68 \%)$ and most were located in the left colon $(53.5 \%)$ (Table I).

The respective operators reported a total of 19 complications (7.8\%), all of them mild. There were 15 early postpolypectomy bleedings (5.1\%), 1 delayed bleeding $(0.4 \%)$ and 1 postpolypectomy syndrome $(0.4 \%)$ as well as 2 episodes of sedationrelated complications (transitory bradycardia during the procedure). All bleeding complications were managed endoscopically, no surgery was required and no procedure-related deaths were reported during this study.

On univariate analysis polyp size and endoscopist volume were the only variables to significantly correlate with the risk of procedurerelated complications (Table II). Bleeding occurred more frequently when larger polyps were resected $(p<0.001$ Mann Whitney U). There were also more complications reported by experienced endoscopists compared to beginner endoscopists $(\mathrm{p}<$ 0.001). However, on multivariate analysis using logistic regression only polyp size was significantly associated with the risk of complications.

Table I

Characteristics of the resected polyps

\begin{tabular}{|c|c|}
\hline & Number (\%) \\
\hline Polyp type & $150(61.5 \%)$ \\
\hline Sessile & $87(35.7 \%)$ \\
\hline Pedunculated & $7(2.9 \%)$ \\
\hline Flat & $166(68 \%)$ \\
\hline Size (cm) & $62(25.4 \%)$ \\
\hline$<1 \mathrm{~cm}$ & $7(2.9 \%)$ \\
\hline $1-2 \mathrm{~cm}$ & $8(3.3 \%)$ \\
\hline $2-3 \mathrm{~cm}$ & $1(0.4 \%)$ \\
\hline $3.4 \mathrm{~cm}$ & $155(53.5 \%)$ \\
\hline$>4 \mathrm{~cm}$ & $89(36.5 \%)$ \\
\hline Location & \\
\hline Left colon & \\
\hline Right colon & \\
\hline
\end{tabular}

Table II

Factors influencing complication rate at colon polypectomy

\begin{tabular}{|c|c|c|}
\hline Variable & Rate of complications & P value \\
\hline \multicolumn{3}{|l|}{ Size (cm) } \\
\hline$<1 \mathrm{~cm}$ & $7 / 166$ & \multirow[t]{5}{*}{$<0.001{ }^{*}$} \\
\hline $1-1.9 \mathrm{~cm}$ & $3 / 62$ & \\
\hline $2-2.9 \mathrm{~cm}$ & $3 / 7$ & \\
\hline $3-3.9 \mathrm{~cm}$ & $4 / 8$ & \\
\hline$>4 \mathrm{~cm}$ & $0 / 1$ & \\
\hline \multicolumn{3}{|l|}{ Endoscopist volume } \\
\hline$<1000$ colonoscopies & $4 / 109$ & \multirow[t]{2}{*}{$<0.001^{*}$} \\
\hline$>1000$ colonoscopies & $13 / 135$ & \\
\hline \multicolumn{3}{|l|}{ Polyp type } \\
\hline Pedunculated & $8 / 87$ & \multirow[t]{3}{*}{0.42} \\
\hline Sessile & $8 / 150$ & \\
\hline Flat & $1 / 7$ & \\
\hline
\end{tabular}




\section{DISCUSSION}

The largest trial on colon polypectomy, the Munchen polypectomy study [3], showed a bleeding rate of approximately $8.6 \%$, accounting for the great majority of procedure-related complications in a survey of almost 4000 polypectomies prospectively reported. In this study, polyp size was the most important risk factor for complications, irrespective of polyp type, but there was no analysis regarding endoscopist-related factors such as case-volume and experience.

In our study, we documented both polyprelated features and endoscopist experience, aiming to verify which factors better correlate with a higher complication rate. On univariate analysis, our data was concordant with data from the Munchen trial, with polyp size significantly correlating with the rate of complications. Polyp type (sessile, pendunculated or flat) did not influence the complication rate $(p=0.42)$. On univariate analysis large volume endoscopists had significantly more complications compared to low-volume endoscopists, but this finding was not confirmed at multivariate analysis where only polyp size was confirmed as a risk factor for complicatios. This finding suggests that the higher rate of complications for experienced endoscopists was very likely a consequence of the fact that large volume endoscopists resected larger polyps, which were more prone to procedurerelated complications.
Since teaching endoscopic polypectomy is part of the daily practice of referral units such as ours, it is important to understand which polyp and endoscopist-related factors need to be considered when planning an intervention, in order to minimize the risk of complications. Data from a prospective trial of difficult polypectomies [8] proved that an even large and difficult polyps can be safely removed in the right setting. In a previous multicenter study of difficult polypectomies [9] our group also showed that difficult colon polypectomies can be safely performed even by lowvolume endoscopists.

The prospective study we have conducted has several limitations: it is a single-center study and the number of reported procedures is relatively low. The main strength of our study is the multivariate analysis which takes into account both polyp and endoscopist-related characteristics influencing the rate of complications.

In conclusion, our findings confirm previous data suggesting that polyp size is the most important risk factor for procedure-related complications, irrespective of polyp type. While both high and low-volume endoscopists seem to have a low rate of overall complications, further studies are warranted to better define which types of polyps are best suited for polypectomy by trainees in order to minimize the rate of complications.

Polipectomia endoscopică colonică scade incidența şi mortalitatea prin cancer colorectal. Mai mulți factori cum ar fi mărimea polipilor, localizarea şi tipul acestora precum şi experiența endoscopistului au fost corelate cu rata de complicații postprocedurale. Studiul de față işsi propune să evalueze impactul factorilor dependenți de polip şi de endoscopist asupra ratei de complicații după polipectomie in practica curentă.

Metode. Pe durata desfăşurării studiului toate polipectomiile efectuate în unitatea noastră au fost raportate folosind un formular standard incluzând date despre tipul polipului (sesil, pediculat, plat), dimensiunile şi localizarea acestuia, metoda de rezecție, experiența endoscopistului şi complicațiile procedurale survenite până la 30 de zile de la polipectomie. Principalul obiectiv a fost indentificarea ratei de complicații legate de polipectomia endoscopică. Factorii corelați cu aceste complicații au fost analizați utilizând analiză uni şi multivariată.

Rezultate. 244 de polipectomii efectuate la 95 de pacienți au fost incluse în analiză. 199 de polipi au fost rezecați de endoscopişti in pregătire (44,7\%) şi 135 de polipectomii au fost efectuate de endoscopişti experimentați (55,3\%). La analiza multivariată doar dimensiunea polipilor s-a corelat $\mathrm{cu}$ riscul de complicații postpolipectomie. 
Concluzii. Dimensiunea polipilor este cel mai important factor de risc pentru complicații postprocedurale, rata complicațiilor postpolipectomie fiind scăzută atât pentru endoscopiştii experimentați cât şi pentru cei aflați în pregătire.

Corresponding author:

\section{REFERENCES}

1. WINAWER SJ, ZAUBER AG, HO MN, et al. Prevention of colorectal cancer by colonoscopic polypectomy. The National Poly Study Workgroup. N Engl J Med 1993, 329: 1977-81.

2. KO CW, DOMINITZ JA. Complications of colonoscopy: magnitude and management. Gastrointest Endosc Clin N Am. 2010; 20(4): 659-671.

3. HELDWEIN W, DOLLHOPFM, ROSCH T, et al. The Munich Polypectomy Study (MUPS): prospective analysis of complications and risk factors in 4000 colonic snare polypectomies. Endoscopy 2005; 37:1116-22.

4. BUDDINGH KT, HERNGREEN T, HARINGSMA J, et al. Location in the right hemi-colon is an independent risk factor for delayed post-polypectomy hemorrhage: a multi-center case-control study. Am J Gastroenterol. 2011; 106(6):1119-1124.

5. CHUKMAITOV A, BRADLEY CJ, DAHMAN B, et al. Association of polypectomy techniques, endoscopist volume, and facility type with colonoscopy complications. Gastrointest Endosc. 2013; 77(3):436-46.

6. GUPTA S, ANDERSON J, BHANDARI P, et al. Development and validation of a nove method for assessing competency in polypectomy. Gastrointest Endosc 2011; 73:1232-9.

7. GUPTA S, MISKOVIC D, BANDARI D, et al. Frontline Gastroenterology 2013. 0:1-5. doi:10.1136/flgastro-2013-100331.

8. BUCHNER AM, GUARNER-ARGENTE C, GINSBERG GG. Outcomes of EMR of defiant colorectal lesions directed to an endoscopy referral center. Gastrointest Endosc. 2012; 76(2):255-63.

9. VOIOSU T, RAȚIU I, HERVOSO CM, et al. Polyp and endoscopist-related factors influencing complication rates in difficult colonic polypectomies: results of a multicenter observational study. Rom J Intern Med. 2013; 51(3-4):172-8.

Received February 11, 2015 